\title{
Books and Media Received ${ }^{\star}$
}

Museum Anthropology Review received the following books, printed catalogs, and media projects for review between December 31, 2016 and May 3, 2017. Publishers and institutions wishing to submit materials for review may send copies to the editorial office: Museum Anthropology Review, Mathers Museum of World Cultures, Indiana University, 416 N. Indiana Ave., Bloomington, IN 47408, USA. Readers of the journal are also encouraged to suggest titles appropriate for review. Not all titles submitted will be reviewed, but every effort will be made to secure reviews of materials appropriate to the scope of the journal. Digital tear sheets will be provided promptly to publishers of works that are reviewed in the journal.

Bennett, Tony, Fiona Cameron, Nelia Dias, Ben Dibley, Rodney Harrison, Ira Jacknis, and Conal McCarthy. Collecting, Ordering, Governing: Anthropology, Museums, and Liberal Government. Durham, NC: Duke University Press, 2016.

Cain, Shawna Morton, and Pamela Jumper Thurman, eds. Cherokee National Treasures: In Their Own Words. Norman: University of Oklahoma Press, 2017.

Colwell, Chip. Plundered Skulls and Stolen Spirits: Inside the Fight to Reclaim Native America's Culture. Chicago: University of Chicago Press, 2017.

Cooper, Melissa L. Making Gullah: A History of Sapelo Islanders, Race, and the American Imagination. Chapel Hill: University of North Carolina Press, 2017.

Denson, Andrew. Monuments to Absence: Cherokee Removal and the Contest over Southern Memory. Chapel Hill: University of North Carolina Press, 2017.

Eburne, Jonathan P., and Benjamin Schreier, eds. The Year's Work in Nerds, Wonks, and Neocons. Bloomington: Indiana University Press, 2017.

Feest, Christian F, and C. Ronald Corum. Frederick Weygold: Artist and Ethnographer of North American Indians. Altenstadt, Germany: ZKF Publishers, 2017.

Klassen, Teri. Tennessee Delta Quiltmaking. Knoxville: University of Tennessee Press, 2017.

Schneider, Arnd. Alternative Art and Anthropology: Global Encounters. London: Bloomsbury Academic, 2017.

Sylvanus, Nina. Patterns in Circulation: Cloth, Gender, and Materiality in West Africa. Durham, NC: Duke University Press, 2017.

Wilkinson, Richard H. The Complete Temples of Ancient Egypt. New York: Thames and Hudson, 2000.

\footnotetext{
* This work is released under the Creative Commons Public Domain Dedication 1.0 Universal. To view a copy of this dedication, visit http://creativecommons.org/publicdomain/zero/1.0/.
} 
Museum Anthropology Review 11(1) Spring 2017

http://dx.doi.org/10.14434/mar.v11i1.23567 